\title{
Erratum to: Formalizing the Logic of Historical Inference
}

\section{L. d'Avray • Antonia Fitzpatrick}

Received: 5 December 2012/Accepted: 5 December 2012/Published online: 8 January 2013

(C) Springer Science+Business Media Dordrecht 2013

\section{Erratum to: Erkenn \\ DOI 10.1007/s10670-012-9382-7}

Due to a technical error, the title of this article is not correct.

The title should read:

Formalizing the Logic of Historical Inference

The online version of the original article can be found under doi:10.1007/s10670-012-9382-7.

D. L. d'Avray $(\bowtie) \cdot$ A. Fitzpatrick

Department of History, UCL, Gower St., London WC1E 6BT, UK

e-mail:ucradav@ucl.ac.uk
A. Fitzpatrick
e-mail: antonia.fitzpatrick@ucl.ac.uk 